\title{
SOME EFFECTS OF PRUNING ON WHITE PINE SEEDLINGS
}

\author{
By K. T. LOGAN 1
}

To determine how severely white pine seedlings could be pruned before growth is affected, two small experiments with 5- and 10-year-old white pine growing in plantations were initiated in 1953 at the Petawawa Forest Experiment Station at Chalk River, Ontario. In one experiment, 32 five-year-old white pine seedlings were selected on the basis of uniform leader growth and size. Height ranged from 12 to 16 inches. They were divided into four groups of 8 seedlings each, and one of the following treatments was made in the spring to each group:

1. All branches pruned except the top whorl.

2. All branches pruned; terminal and lateral buds left.

3. All branches pruned; only terminal bud left.

4. Untreated control.

In the second experiment, 40 ten-year-old white pine between 3 and 4 feet tall were selected in a similar manner and divided into five groups. Mean height of the groups ranged from 3.5 feet to 3.9 feet. In one group, two whorls of branches were left. Other treatments were the same as above.

To maintain the treatment condition, the lowest whorl of branches was removed each spring for three successive years. Leaders on the 10-year-old seedlings were sprayed with a solution of DDT early in May each year, with the result that there was very little damage from the white pine weevil (Pissodes strobi Peck). The younger seedlings were not attacked. At the end of each growing season the following measurements were taken: height, leader length, leader diameter, length of branch in top whorl, needle length. The experiments were concluded at the end of three growing seasons.

Results from treatments after three years of pruning are summarized in Table 1. Ten-year-old seedlings having only two whorls of branches remaining were substantially the same as unpruned seedlings in height, branch length, needle length, and diameter of leader. Although there were no 5-year-old seedlings with two whorls of branches, it is assumed that they would have behaved similarly. Seedlings having fewer than two whorls were about one foot shorter than the others at the end of three years. Their branches were about three inches shorter and leader diameters about two millimeters less, except on the debudded seedlings which, until the final year, usually had diameters equal to or greater than controls. During the first two years of treatment debudded seedlings also had longer needles. Five of the pruned and debudded 10-year-old seedlings and three seedlings with only terminal and lateral buds died as a result of the most severe treatment.

${ }^{1}$ Forest Research Officer, Forest Research Division, Department of Northern Affairs and National Resources, Petawawa Forest Experiment Station, Chalk River, Ontario. 
Hicock (2) reported similar results for red pine seedlings, and Bickerstaff (1) reported that debudded red pine had longer needles and greater diameter of the leader.

The results show that 5- to 10-year-old white pine can stand severe pruning before their growth is materially affected. Although it was beyond the scope of the present investigation, they also suggest that a periodic pruning of the lowest whorl of branches might be a suitable alternative to debudding to produce a relatively knot-free butt log. Pruned seedlings sometimes formed adventitious buds; as many as a dozen were found on seedlings that were completely pruned and debudded, but very few on seedlings with lateral buds or branches.

The typical older age class of seedlings is illustrated in Figures 1 to 5 by photographs taken during the fall when there was an additional whorl on each treatment. (Please see page 111.)

TABLE 1

The Effects of Different Types of Pruning on the Growth OF 5-YEAR-OLD AND 10-YeAR-OLD WHITE PINE

\begin{tabular}{|c|c|c|c|c|c|c|c|c|}
\hline \multirow[b]{2}{*}{ Treatment } & \multicolumn{2}{|c|}{$\begin{array}{l}\text { Height } \\
\text { (feet) }\end{array}$} & \multicolumn{2}{|c|}{$\begin{array}{l}\text { Branch length } \\
\text { (inches) }\end{array}$} & \multicolumn{2}{|c|}{$\begin{array}{l}\text { Needle length } \\
\text { (inches) }\end{array}$} & \multicolumn{2}{|c|}{$\begin{array}{c}\text { Leader } \\
\text { diameter } \\
\text { (millimeters) }\end{array}$} \\
\hline & $\begin{array}{l}5-8 \\
\text { yrs. } \\
\text { old }\end{array}$ & $\begin{array}{l}10-13 \\
\text { yrs. } \\
\text { old } \\
\end{array}$ & $\begin{array}{l}5-8 \\
\text { yrs. } \\
\text { old }\end{array}$ & $\begin{array}{l}\text { 10-13 } \\
\text { yrs. } \\
\text { old }\end{array}$ & $\begin{array}{l}5-8 \\
\text { yrs. } \\
\text { old } \\
\end{array}$ & $\begin{array}{c}10-13 \\
\text { yrs. } \\
\text { old }\end{array}$ & $\begin{array}{l}5-8 \\
\text { yrs. } \\
\text { old }\end{array}$ & $\begin{array}{c}10-13 \\
\text { yrs. } \\
\text { old }\end{array}$ \\
\hline Control & 4.0 & 6.6 & 9.1 & 8.9 & 2.7 & 3.8 & 7.5 & 5.7 \\
\hline Two whorls left ${ }^{1}$ & - & 6.9 & - & 8.4 & - & 3.3 & - & 4.9 \\
\hline $\begin{array}{l}\text { One whorl left } \\
\text { Terminal \& lat- }\end{array}$ & 3.1 & 5.6 & 6.5 & 6.8 & 2.7 & 3.3 & 5.3 & 4.2 \\
\hline $\begin{array}{l}\text { Terminal \& lat- } \\
\text { eral buds left }\end{array}$ & 3.0 & 5.4 & 6.3 & 5.0 & 2.6 & 3.5 & 4.8 & 3.7 \\
\hline Terminal bud left ${ }^{2}$ & 3.2 & 5.4 & - & - & 3.4 & 3.5 & 7.4 & 5.0 \\
\hline
\end{tabular}

${ }^{1}$ No 5 -year-old seedlings in this treatment.

No branches in this treatment.

\section{REFERENCES}

1. BICKERSTAFF, A. 1945. Knot-free red pine by debudding. Canzda, Dept. of Mines a Resources, Dominion Forest Service, Silvicultural Res. Note No. 76.

2. HICOCK, H. W. 1931. Pruning in young plantations. J. For. 29: 541.543. 


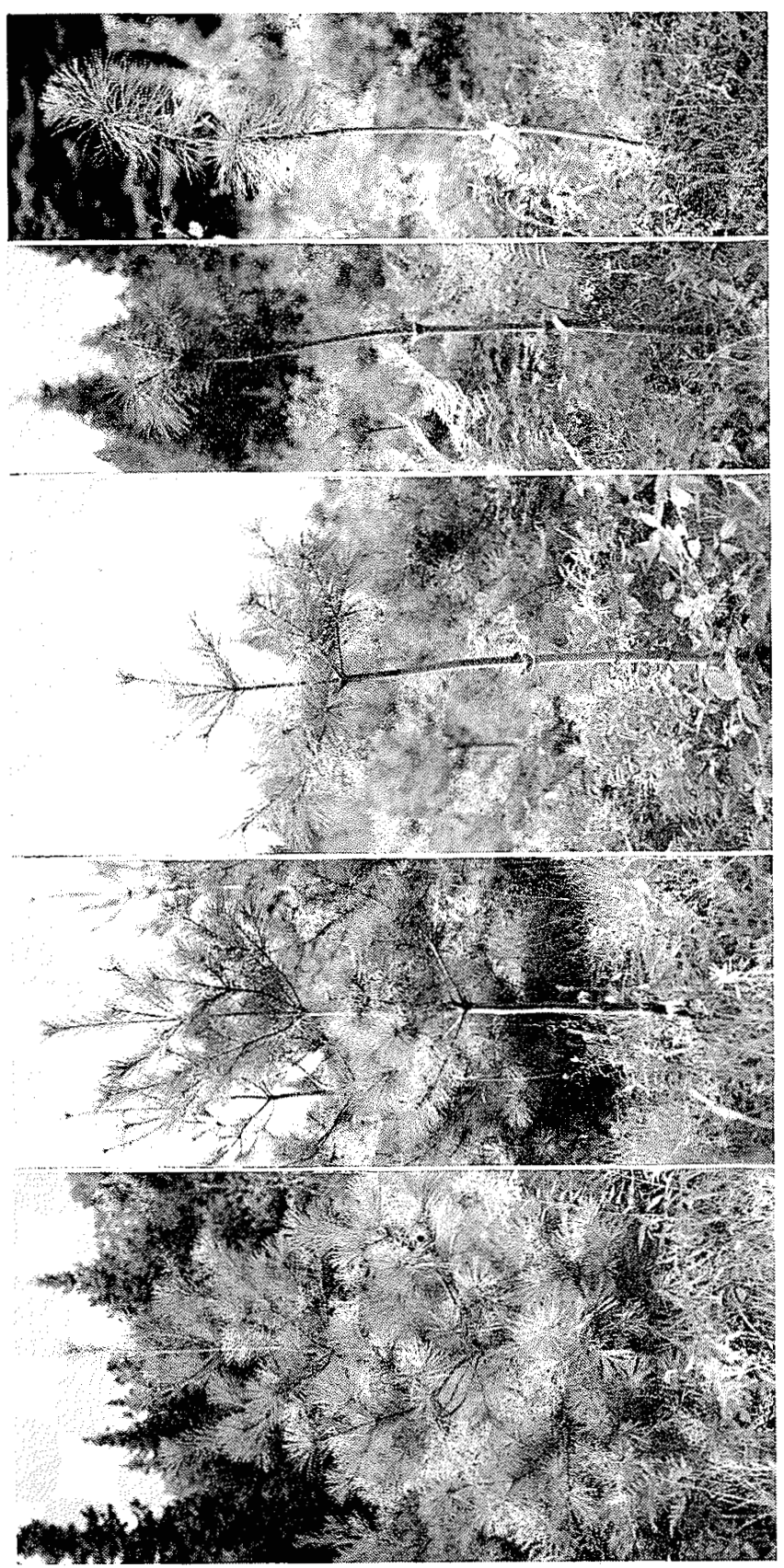

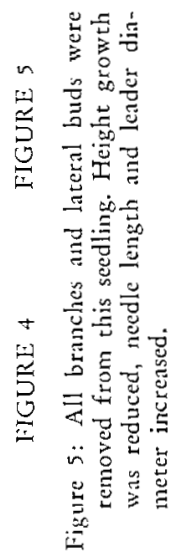

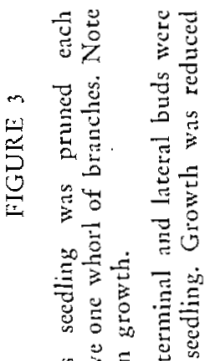

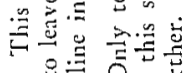

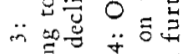

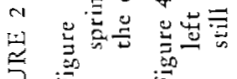

苞

嵒㟔

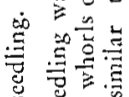

造

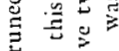

를

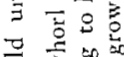

- 궁

ज्ञ

5 ô

0 耘

$\because$ 开

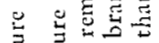

密蛋 


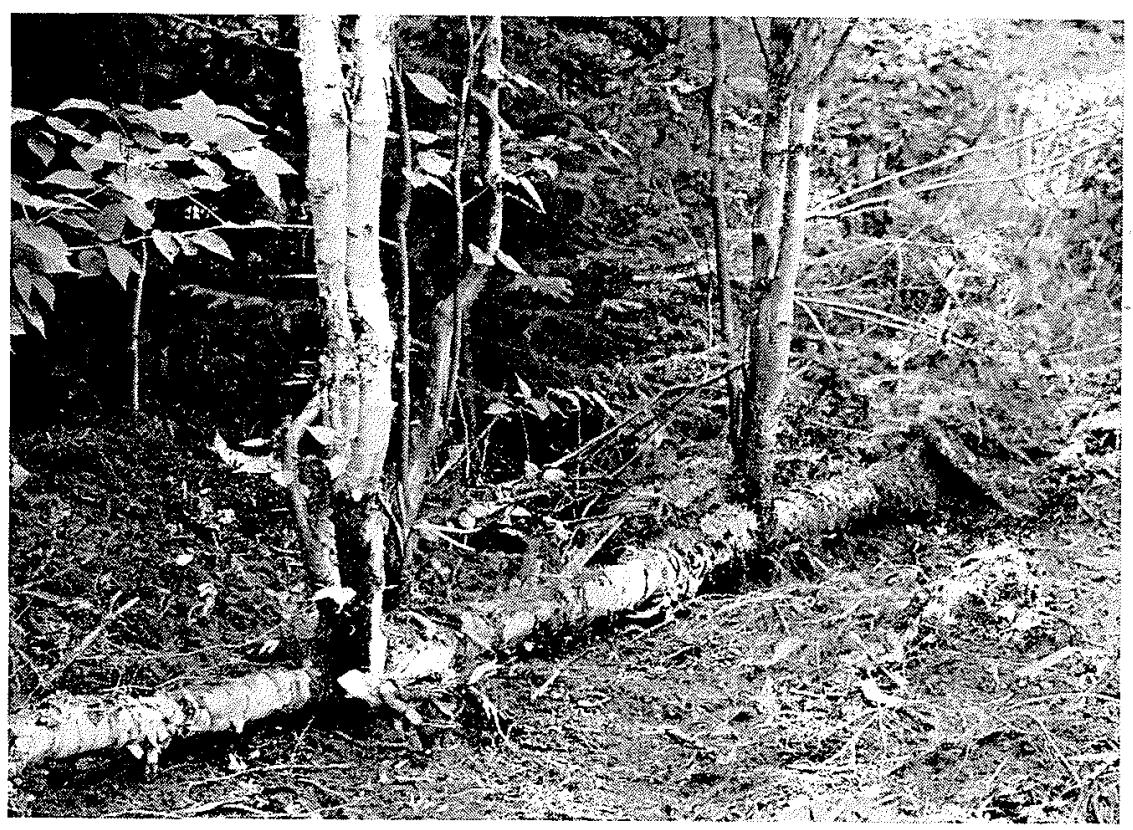

FIGURE 1

An unusual case of vegetative reproduction of White Birch. 